\title{
Possible climate change impacts on large hydroelectricity schemes in Southern Africa
}

\author{
P Mukheibir \\ Energy Research Centre, University of Cape Town
}

\begin{abstract}
There is growing concern that developing countries, such as South Africa, should reduce their coal dependence for energy generation and look to other cleaner technologies. Hydroelectricity is one such option. A number of potential large hydro sites have been identified in Southern Africa, which form part of the Southern African Power Pool. However, limited information exists on the impact of climate change on these sites and its effect on the viability of the hydroelectric schemes. Using downscaled global circulation model information, projected climate impacts and the potential impact these may have on future hydro schemes are discussed.
\end{abstract}

Keywords: climate change impacts, hydroelectricity schemes, Southern Africa, greenhouse gas emissions

\section{Introduction}

Increases in greenhouse gas concentrations look set to rise given the threefold increase in energy demand expected by 2100 . With a rising demand for electricity globally, the likely increase in fossilfuel prices and the need for clean energy sources, renewable energy sources, including hydro power, appear more attractive. Hydropower production is set to increase threefold over the next century (Nakicenovic et al 1998). Future plans for new hydroelectric plants, however, will need to consider three major factors. Private capital may not favour hydropower, since such facilities do not have short repayment periods and high returns. Such investments are best suited for public investment, which have to compete for other social services. Secondly, hydroelectric plants based on large dams are not environmentally neutral. Thirdly, potential declining river flows due to climate change impacts may lead to declining hydropower production, which in turn, will have an impact on the financial viability of such schemes (Harrison \& Whittington 2002). For example, Eastern African countries such as Kenya and Tanzania, have in the past decade experienced electricity shortages from hydroelectric plants due to drought.Given its dependence on coal for electricity generation, hydroelectricity could be the key source that reduces South Africa's greenhouse gas (GHG) emissions. Large hydro schemes in the Congo and Mozambique could play a major role in providing an alternative electricity source for South Africa. However, climate change has the potential to impact on these initiatives, both positively and negatively.

Using two regional climate models (RCMs) Tadross et al. have downscaled 10 years of control and 10 years of future (2070-2079) Southern African climate conditions, as simulated by the HadAM3 general circulation model forced with the A2 SRES emissions scenario. Changes in early and late summer total rainfall and average surface temperature are presented for the projected future climate (Tadross et al. 2005). Based on this information, the potential impacts of climate change on hydroelectric potential are discussed.

\section{Key sectors for South Africa's GHG emissions}

South Africa is a semi-industrialised country with an emissions profile that in some respects is not typical of a developing country. In terms of global environmental impacts, South Africa is one of the most carbon-emission intensive countries in the world, with per capita $\mathrm{CO}_{2}$ emissions higher than those of some European countries (see Table 1) (IEA 2002). This 
is partly the result of its coal-based energy economy and the high specific energy intensity of many sectors. The greenhouse gas emissions per unit of economic output are high (IEA 2001).

Table 1: Energy sector carbon dioxide emissions intensity and per capita in $\mathbf{2 0 0 2}$ Source: IEA (2004)

\begin{tabular}{lccc}
\hline & $\begin{array}{c}\mathrm{CO}_{2} / \text { cap } \\
\text { tonnes/capita }\end{array}$ & $\begin{array}{c}\mathrm{CO}_{2} / \mathrm{GDP} \\
\mathrm{Kg} / 1995 \text { US } \$\end{array}$ & $\begin{array}{c}\mathrm{CO}_{2} / \text { GDP PPP } \\
\mathrm{kg} / 1995 \text { PPP US } \$\end{array}$ \\
\hline South Africa & 6.65 & 1.65 & 0.75 \\
\hline Africa & 0.89 & 1.16 & 0.45 \\
\hline Non-OECD & 1.65 & 1.33 & 0.45 \\
\hline OECD & 10.96 & 0.44 & 0.56 \\
\hline World & 3.89 & 0.68 & 0.56 \\
\hline Note: $\mathrm{CO}_{2}$ from fuel combustion only
\end{tabular}

The energy sector in South Africa, including energy production and use, contributed $78 \%$ of GHG emissions in 1994. As is illustrated in Figure 1 , energy is the primary source of GHG emissions, with the most significant contribution coming from energy production industries $(45 \%$ of total gross emissions).

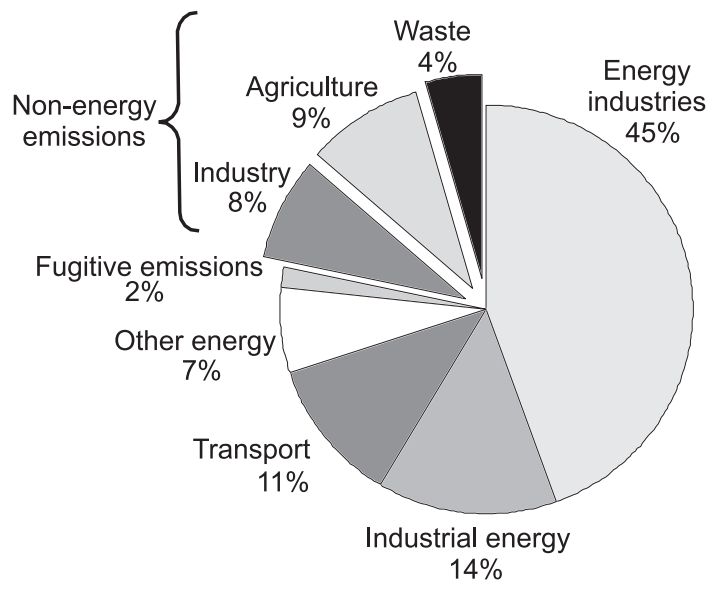

Figure 1: South Africa's greenhouse gas inventory by sector, 1994

Source: Van der Merwe \& Scholes (1998)

More specifically, greenhouse gas (GHG) emissions from electricity generation make up most of the South Africa's energy industry emissions (Van der Merwe \& Scholes 1998). Therefore, the mitigation potential for South Africa lies primarily in the energy sector and more specifically in the electricity generation sector.

Coal represents the largest source of energy for sent out electricity and is the main reason for the high GHG emissions for electricity generation. In future South Africa, is likely to build more conventional coal stations to meet the growing demand for electricity, which will increase the GHG emissions.
Table 2: Net electricity sent out (GWh) by fuel Source: NER (2001)

\begin{tabular}{lcc}
\hline & Total & $\begin{array}{c}\text { Share of total energy } \\
\text { sent out }\end{array}$ \\
\hline Coal & 189900 & $93.2 \%$ \\
\hline Nuclear & 11961 & $5.9 \%$ \\
\hline Pumped storage & -816 & $-0.4 \%$ \\
\hline Hydro & 2382 & $1.2 \%$ \\
\hline Bagasse & 259 & $0.1 \%$ \\
\hline Gas & 5 & $0.003 \%$ \\
\hline Total & $\mathbf{2 0 3 6 9 2}$ & \\
\hline
\end{tabular}

Note: Negative values: Pumped storage uses more electricity in pumping water up than it generates, and hence is a net consumer. For gas (using aeronautical diesel fuel in jet turbines), Acacia station consumed more for own use in its generation process than it generated in 2000 . This is not always the case.

There are some plans for new clean coal technologies such as supercritical, fluidised bed combustion and integrated gasification combined cycle plants. Desulphurisation is likely to be used for new conventional stations, although this will considerably increase capital and running costs (Kenny \& Howells 2001).

Cleaner electricity generation options with low GHG emissions would include imported natural gas feeding into combined cycle gas turbines (CCGTs), the Pebble Bed Modular Reactor (PBMR), renewable energy and imported hydro.

Importing hydroelectricity from the Southern African region is one of the major options for diversifying the fuel mix for meeting the growing demand for electricity in South Africa. South Africa uses hydro to meet only $1.2 \%$ of its electricity demand and currently imports electricity from the Cahora Bassa Dam in Mozambique. However, this is small in comparison with the potential at Inga Falls in the Democratic Republic of Congo (DRC), estimated to range between $40 \mathrm{GW}$ for run-of-river to $100 \mathrm{GW}$ for the entire Congo basin (Games 2002; Mokgatle \& Pabot 2002).

\section{Mitigation and adaptation linkage}

The connection between sustainable development and climate change works in two directions, viz through mitigating greenhouse gas emissions and secondly adapting to the projected impacts due to global warming (Munasinghe \& Swart 2005). In South Africa, this two-way connection is of particular interest in the energy sector. As is illustrated in Figure 2, South Africa needs to investigate mitigation options against GHG emissions such as imported large hydro, but also need to consider the impacts of climate change on this source of energy.With this in mind, a scoping study was undertak- 
en of the potential impacts of climate change on large hydros in Southern Africa (Winkler et al. 2006).

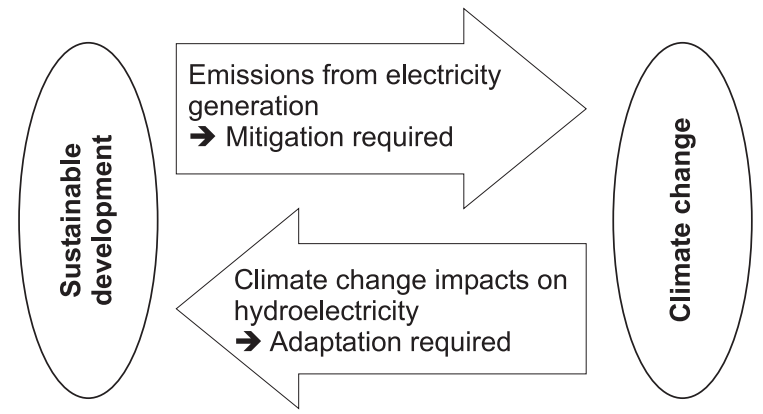

Figure 2: Two-way interaction between sustainable development and climate change

\section{Major sources of hydroelectricity in Southern Africa}

The Southern African power grid is becoming more interconnected. Major plans under the New Partnership for Africa's Development (NEPAD) include proposed inter-connectors, as can be seen in Eskom plans shown in Figure 3. A central feature of this map from a South African perspective includes importing hydroelectricity from Inga Falls in the DRC (40 GW potential).

\subsection{Inga Falls - DRC}

The DRC currently has $1.7 \mathrm{GW}$ of electricity generating capacity at its Inga hydroelectric facility. A 3.5 GW expansion (Inga 3) is planned and will be coupled with the rehabilitation of Inga 1 and 2 (Hayes 2005; Poggiolini 2005). The proposed Grand Inga would have a capacity of 39 GW . Even the run-ofriver capacity would match South Africa's current total generation capacity.

The Western Power Pool, of which the Inga plants would be a crucial part, would need to overcome a number of hurdles. Technical problems such as insufficient transmission capacity and line losses over long distances would need to be overcome to ensure reliability (Kenny \& Howells 2001). Furthermore, the interconnections between the national grids within the Southern African Power Pool (SAPP) would need to be strengthened (Mlambo-Ngcuka 2003). Political stability in the $\mathrm{DRC}$ is also a critical pre-requisite for using this option.Inga Falls is not the only potential site in Southern Africa. Plans for increasing hydroelectric imports from Mozambique to South Africa are another option.

\subsection{Mepanda Uncua and Cahora Bassa - Mozambique}

South Africa already imports electricity from the Cahora Bassa Dam in Mozambique (5294 GWh in 2000) (NER 2000). The Mepanda Uncua site in Mozambique is located on the Zambezi River downstream of Cahora Bassa, and has a potential for $1300 \mathrm{MW}$ and an annual mean generation of 11 TWh. Installed capacity of $1300 \mathrm{MWe}$ at a plant factor of $64 \%$ provides $7288 \mathrm{GWh} /$ year (NER 2004).

\section{Potential impacts of climate change on regional temperature and run-off}

The Climate Systems Analysis Group (CSAG), based at the University of Cape Town, has devel-

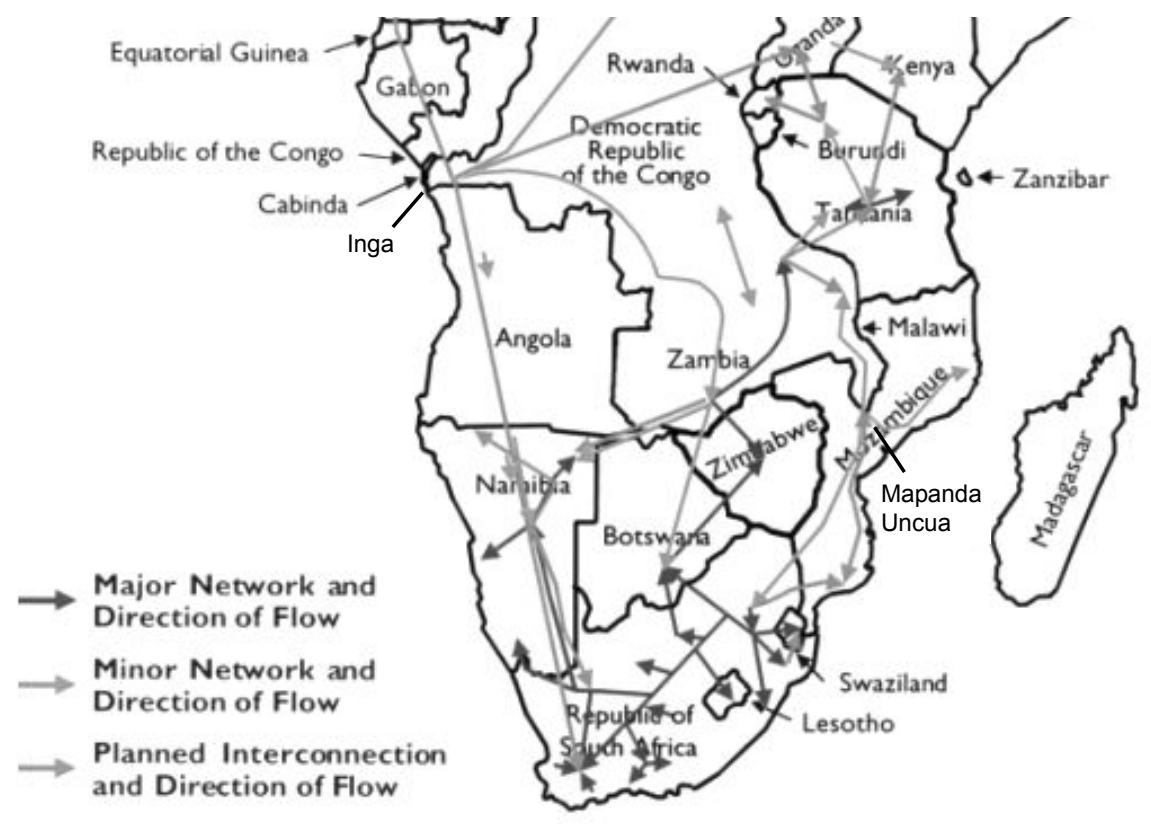

Figure 3: Existing and planned Africa connector map Source: NER 2003, citing Eskom 
oped climate projection scenarios for the Southern African region. The climate change outputs from the models currently being used produce different simulations. Whilst there are still many uncertainties with regard to the magnitude, the direction of change appears to be consistent (Hewitson et al. 2005).Climate change manifests itself in two distinct ways viz. change in temperature and change in rainfall. The projections and the likely impacts on hydroelectric installations are discussed further.

\subsection{Change in temperature}

Observational records demonstrate that the African continent has been warming through the 20th century at the rate of about $0.05^{\circ} \mathrm{C}$ per decade, with slightly larger warming in the June to November seasons than in December to May (Hulme et al in UNEP 2002). By the year 2000, the 5 warmest years in Africa had all occurred since 1988, with 1988 and 1995 being the two warmest years.

The 2070 projections for temperature in Southern Africa, indicate an increase everywhere, with the greatest increase inland and the least in the coastal regions. Temperature is expected to increase by approximately $1^{\circ} \mathrm{C}$ along the coast and $3-5^{\circ} \mathrm{C}$ inland of the coastal mountains (Tadross et al. 2005). Along with temperature increases, changes in evaporation are anticipated. Increases in temperature will have a corresponding increase in evaporation. The converse is also true.

\subsection{Change in rainfall}

Currently, the equatorial area of sub-Saharan African receives the most rainfall, whilst the south western area receives the least (UNEP 2002).Using the results of the simulated change for 2070 in seasonal rainfall, it can be observed that both $\mathrm{RCM}$ models predict drying over the tropical western side of the sub-continent, for the months of Oct-NovDec. For Jan-Feb-Mar, the models indicate drying to the west in the tropics, and an increase in precipitation to the east and south east. . This is consistent with the statistical downscaling of multiple GCMs by Hewitson and Crane (2006).

\section{Potential impacts of climate change on regional hydroelectricity}

The change in temperature and rainfall has the potential to affect hydroelectric installations in four major ways:

i) Surface water evaporation

ii) Reduced run-off due to drought

iii) Increased run-off due to flooding

iv) Siltration deposits

\subsection{Evaporation}

The greatest loss of potential water resources from hydroelectric facilities comes from the evaporation of water from the surface of reservoirs. This loss of water would otherwise have been available for downstream uses as well as for the generation of electricity. Evaporation losses per annum have been calculated to be on average 1.1 metres of depth per square kilometre of surface area. This could be much higher depending on the climate of the region. For example, this figure for the Aswan High Dam on the Nile River is $2.7 \mathrm{~m}, 11 \%$ of the reservoir capacity (Gleick 1994).

A study conducted in California showed that hydroelectric facilities have average environmental losses of $5.4 \mathrm{Kl}$ of water per $10 \mathrm{MWh}$ electricity produced (Gleick 1994). Deep dams with smaller surface areas would be less affected that those with large surface areas.

Increasing temperature generally results in an increase in the potential evaporation and given that temperature is expected to increase globally it can be expected that evaporation on large open waters would increase. For both the Congo and Zambezi catchments, the temperature is expected to increase.

Changes in other meteorological controls may exaggerate or offset the rise in temperature, such as wind speed and humidity. In humid regions, atmospheric moisture content is a major limitation to evaporation, so changes in humidity have a very large effect on the rate of evaporation (IPCC 2001).

The catchment area for the Congo River is in a high humidity area and therefore the potential for increased evaporation would be low, whilst that of the Zambezi River is less humid and would have a higher potential for evaporation.

\subsection{Reduced run-off}

The direct impact of drought is that the run-off is reduced and consequently the storage in dams is negatively affected. Because the duration of droughts can not be predicted with any certainty, it may be necessary to impose restrictions on the use of water. In South Africa, where restrictions are necessary, water to meet basic needs will always receive priority in allocations, followed by strategic uses such as power generation and key industries. In general, water for irrigation is restricted first (DWAF 2004).

Climate change models indicate minimum changes in the hydrology of the Congo Basin, whereas other basins have significant vulnerability to climate change (IPCC 2001).

In recent years there have been some interruptions in some hydropower plants as a result of severe drought. In Zimbabwe, Kariba contributes $50 \%$ of the electricity needs, but generation dropped by $8 \%$ due to drought in 1992 (Chenje \& Johnson 1996). Kenya and Tanzania were forced in 2000 to ration electricity since the hydroelectric plants has been affected by persistent drought (Ongeri 2000). After the drought in 2004, all of 
Tanzania's hydroelectric plants were operating at half capacity (EIA 2005).

For both the Congo and Zambezi catchments, however, the average annual rainfall is expected to increase.

\subsection{Flooding}

Given that there is a predicted increase in annual rainfall and that this may be due to increased rainfall intensity and reduced rain days (Tadross et al. 2005), the occurrence of increased flooding can be expected.

Unexpected flooding can be detrimental to large dams where the large loads of sediments carried by the rivers settle in the dams and lakes. For in-stream hydro plants, large logs and vegetation can cause damage or block up the system. However, in some cases, the increased volume of water could allow for increased generation potential.

\subsection{Siltration}

Siltration refers to the deposition of particles of the river load. Siltration is the consequence of erosion which is prevalent in some part of Southern Africa where rains and consequently rivers can be aggressive. Non-existent or sparse vegetation and the desiccation of soils during dry seasons can make the soils particularly vulnerable to the water action.

Siltration is considered a major threat as it lessens the life span of dams and irrigation structures by reducing the depth of dams and hence the storage capacity. This can reduce the potential of dams to generate hydroelectricity.

The construction of berms and swales upstream would help reduce siltration in areas where the erosion potential is high. This would most likely be relevant to the Zambezi River.
For the Zambezi catchments, climate change is projected to increase both the temperature as well as the annual rainfall. The impact of this will potentially result in increasing evaporation on installations with large dams such as those on the Zambezi. In addition, it would result in an increase in the volume of water per annum, which could include periodic flooding, that may in turn increase the amount of sedimentation in erosion prone areas. Some measures to reduce siltration might be needed on the Zambezi River. There is little chance of drought impacts and reduced run-off.

Climate change models initially indicate minimum changes in the hydrology of the Congo River Basin. The impact of evaporation on this river basin is negligible, since the humidity is relatively high and the key installation, the run of river power plant, does not have any large dams or open waters.

\section{Conclusions}

The increased use of hydropower is a key strategy to reducing the extent of future climate change due to GHG emissions. Based on this initial assessment, a further investigation is required on a case by case basis to assess the potential impact of a change in climate on the catchment sites for future planned large hydroelectric installations.

Specific studies for these catchments are required to ascertain the magnitude of these impacts. The consideration of specific adaptation interventions at design and operation stages will need to be based on the projections from regional climate models. Improved confidence levels are needed for the results of these projections for planners to consider their implications without having to integrate wide ranging scenarios.

\section{Summary}

The overall assessment of climate change impacts on potential hydroelectricity in Southern Africa is shown in Figure 4.

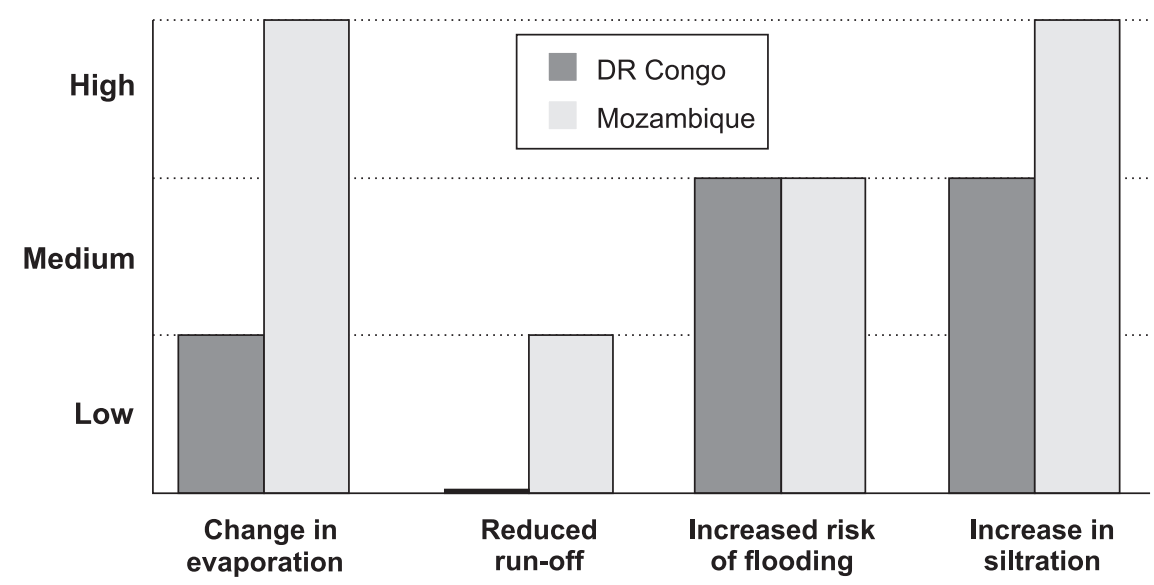

Figure 4: Potential impact of climate change on hydroelectric facilities in Southern Africa 


\section{References}

Chenje, M \& Johnson, P (Eds) 1996. Water in Southern Africa. Harare, SADC Environment and Land Sector Coordination Unit.

DWAF 2004. National Water Resource Strategy. First Edition. September 2004.

EIA 2002. Inga Hydro. www.eia.doe.gov/emeu/cabs/ inga.html .

EIA 2005. The Southern African Development Community. Washington DC, US Department of Energy.

Games, D 2002. Pooling resources: Special report Eskom. Business in Africa July / August: 50-51.

Gleick, P 1994. Water and Energy. Annual Reviews Energy Environment 19: 267-299.

Harrison, G \& Whittington, H 2002. Susceptibility of the Batoka Gorge hydroelectric scheme to climate change. Journal of Hydrology 264: 230-241.

Hayes, R 2005. Inga set to fly at last. African Energy Journal 17 (5): 6-9.

Hewitson, B, Tadross, M \& Jack, C 2005. Scenarios from the University of Cape Town. In: Schulze, R.E. (Ed) Climate Change and Water Resources in Southern Africa: Studies on Scenarios, Impacts, Vulnerabilities and Adaptation. Pretoria, Water Research Commission. WRC Report 1430/1/05: Chapter 3: 39 $-56$.

Hewitson, B C \& Crane, R G 2006. Consensus between GCM climate change projections with empirical downscaling: precipitation downscaling over South Africa. International Journal of Climatology 26 (10): 1315-1337.

IEA (International Energy Agency) 2001. Key World Energy Statistics from the IEA. Paris, IEA.

IEA (International Energy Agency) 2002. Key World Energy Statistics from the IEA. Paris, IEA.

IEA (International Energy Agency) 2004. Key World Energy Statistics from the IEA. Paris, IEA.

IPCC 2001. Climate Change 2001: Impacts, adaptation and vulnerability. Contribution of Working Group II to the Third Assessment Report. J J McCarthy, O F Canziania, N A Leary, D J Dokken and K S White. Cambridge, Cambridge University Press for Intergovernmental Panel on Climate Change.

Kenny, A \& Howells, M 2001. Energy futures: trends and options for the world and for South Africa, with emphasis on the generation of electricity. Energy Management News June. 7 (2): 10-17.

http://www.eri.uct.ac.za/Energy\%20Managment\%20New s/June2001/01.pdf.

Mlambo-Ngcuka, P 2003. Budget vote speech by Minister of Minerals and Energy, Ms. Phumzile Mlambo-Ngcuka. Minerals and energy: a catalyst in pushing back frontiers of poverty. Cape Town, Parliament. 15 May 2003.

Mokgatle, D \& Pabot, J L 2002. Highlighting the opportunities for taking the energy grid across Africa. 4th Annual Sub-Saharan Power Conference, Midrand, 19-21 February.
Munasinghe, M \& Swart, R 2005. Primer on climate change and sustainable development: Facts, policy analysis and applications. Cambridge, Cambridge University Press.

Nakicenovic, N, Grubler, A \& McDonald, A (Eds) 1998. Global energy perspectives. Cambridge, Cambridge University Press for International Institute for Applied Systems Analysis and World Energy Council.

NER (National Electricity Regulator) 2000. Electricity supply statistics for South Africa 2000. Pretoria, NER.

NER (National Electricity Regulator) 2001. Electricity supply statistics for South Africa 2001. Pretoria, NER.

NER (National Electricity Regulator) 2004. National Integrated Resource Plan 2 (NIRP2) 2003/4. Pretoria, National Electricity Regulator. www.ner.org.za.

Ongeri, J 2000. Drought stricken Tanzania rations electricity. Afrol News. November.

Poggiolini, D 2005. On route to an African power highway. African Energy 7 (6): 6-11.

Tadross, M, Jack, C \& Hewitson, B 2005. On RCM-based projections of change in Southern African summer climate. Geophysical Research Letters 32. 15 December 2005.

UNEP 2002. Vital climate graphics Africa. UNEP/GRIDArenda.

Van der Merwe, M R \& Scholes, R J 1998. South African Greenhouse Gas Emissions Inventory for the years 1990 and 1994. Pretoria, National Committee on Climate Change.

Winkler, H, Mukheibir, P \& Mwakasonda, S 2006. Electricity supply options, sustainable development and climate change: Case studies for South(ern) Africa. Draft. Energy Research Centre, University of Cape Town.

Received 2 November 2007; revised 12 January 2007 